\title{
Responses of loggerhead sponges Spechiospongia vesparium during harmful cyanobacterial blooms in a sub-tropical lagoon
}

\author{
Charles C. Wall*, Brooke S. Rodgers, Christopher J. Gobler, Bradley J. Peterson
}

School of Marine and Atmospheric Sciences, Stony Brook University, Stony Brook, New York 11794-5000, USA

\begin{abstract}
Shallow, coastal lagoons are vulnerable to eutrophication and harmful algal blooms, often due to the loss of benthic suspension feeders. Florida Bay, USA, is a sub-tropical lagoon that has suffered from a series of ecological disturbances, including cyanobacterial blooms, loss of seagrass habitat, and widespread sponge mortality. A field study was executed at sites across Florida Bay to investigate effects of cyanobacterial blooms of the genus Synechococcus on the suspensionfeeding loggerhead sponge Spheciospongia vesparium. In situ measurements of loggerhead sponge survival, water pumping rates, and particle retention were made over the course of a year under both bloom and non-bloom conditions and for naturally-occurring and transplanted sponges. The mortality of transplanted loggerhead sponges significantly increased following cyanobacterial blooms. Sponge water pumping rates, particle retention, and filtration rates were depressed in areas where cyanobacteria blooms were present. When loggerhead sponge community filtration rates were compared with cyanobacteria intrinsic growth rates, sites with low abundances of sponges had persistent, dense blooms and harbored positive net growth rates for cyanobacteria ( 0.78 to $\left.1.45 \mathrm{~d}^{-1}\right)$. In contrast, sites with high abundances of sponges had few or no blooms and net growth rates for cyanobacteria that were slow or negative $\left(-0.17\right.$ to $\left.0.24 \mathrm{~d}^{-1}\right)$. This suggests that the loss of filtration from sponge mortality in Florida Bay has contributed to the persistence of algal blooms. Restoration of benthic suspension feeders such as sponges could be an important management tool to mitigate algal blooms in shallow coastal lagoons, although survival of transplanted populations will likely require concurrent improvement of water quality by other means since blooms inhibit sponge pumping, particle retention, and filtration.
\end{abstract}

KEY WORDS: Florida Bay · Sponges - Spheciospongia vesparia · Loggerhead sponge · Cyanobacteria $\cdot$ Synechococcus $\cdot$ Harmful algal bloom

\section{INTRODUCTION}

Harmful algal blooms are increasing world-wide (Hallegraeff 1993, Lotze et al. 2006) and have led to human health concerns, loss of benthic habitats, and damage to estuarine resources (Gobler et al. 2005, Sunda et al. 2006). Many of these algal blooms can be linked to eutrophication (Anderson et al. 2008, Heisler et al. 2008) or loss of benthic filtration (Newell 1988, Lotze et al. 2006). Benthic suspension feeders can filter the water column quickly enough to suppress blooms of phytoplankton in some systems (Officer et al. 1982, Cerrato et al. 2004, Wall et al. 2008), and such top-down control should be more prevalent in ecosystems that are shallow and have a high density of consumers (Smaal \& Prins 1993, Heck \& Valentine 2007), such as shallow coastal lagoons. Since coastal lagoon systems often have extended physical turnover times, which makes them more vulnerable to harmful micro-algal blooms (Cloern 
2001), the loss of benthic suspension feeders from such a system likely represents a more significant loss of top-down control than for deeper, well-flushed ecosystems.

Florida Bay, USA, is a shallow, sub-tropical lagoon between mainland Florida and the Florida Keys; it is the largest estuary in Florida, valuable for recreation and fisheries, and adjacent to the sensitive habitats of the Florida Keys National Marine Sanctuary and Everglades National Park. Since the late 1980s, Florida Bay has been affected by a series of ecological disruptions, including sponge die-offs (Butler et al. 1995), blooms of the cyanobacteria Synechococcus spp. (Phlips et al. 1999), and seagrass mortality (Robblee et al. 1991). The root cause of these disturbances may be linked to human alterations of the freshwater flow in the Everglades, which is upstream of Florida Bay (Phlips et al. 1999, Nuttle et al. 2000). These ecological disruptions have resulted in widespread loss of benthic habitat for juvenile fish and spiny lobster (Robblee et al. 1991, Butler et al. 1995) and a loss of benthic filtration from suspensionfeeding sponges (Peterson et al. 2006). These changes could initiate a 'regime shift' from a benthicdominated system to a pelagic-dominated system in some regions of Florida Bay (Chasar et al. 2005), which is remarkable considering this system has an average depth of only $1 \mathrm{~m}$ (Nuttle et al. 2000). As such, Florida Bay could be considered an ideal case study of eutrophication and loss of benthic filtration in a shallow coastal lagoon.

The dominant benthic suspension feeders in Florida Bay are sponges, especially the loggerhead sponge Spheciospongia vesparium (Butler et al. 1995, Lynch \& Phlips, 2000). Loggerhead sponges are fully heterotrophic, with a high abundance of microbial endosymbionts (Weisz et al. 2008). Sponges, along with octocorals and solitary hard corals, are a key component of the Florida Bay benthic community, providing structural habitat for juvenile octopus, stone crabs, and spiny lobster Panulirus argus (Butler et al. 1995). In the early 1990s, there were a series of widespread sponge die-offs in Florida Bay that affected $>40 \%$ of the loggerhead sponges and $>70 \%$ of other sponge species (Butler et al. 1995). Cyanobacterial blooms which occurred during sponge mortality are a putative cause (Butler et al. 1995), although subsequent laboratory-based experiments have failed to show a direct toxic effect by Synechococcus on sponges (Lynch \& Phlips, 2000, Peterson et al. 2006). The precise causes of micro-algal blooms and sponge mortality in Florida Bay have yet to be resolved.
Persistent, dense blooms of cyanobacteria $\left(>10^{6}\right.$ cells $\mathrm{ml}^{-1}$ ) have the potential for disrupting the ecology of estuaries through associated hypoxia, toxin production, being a poor source of food for filter feeders, and/or the reduction of light availability for benthic plant communities (Phlips \& Badylak 1996, Phlips et al. 1999, Sunda et al. 2006). An understanding of the bottom-up and top-down controls on Synechococcus blooms in Florida Bay will be crucial to successful ecosystem management and may provide clues to aid management of other coastal lagoons. Anthropogenic nutrient loading has been a problem in several areas of south Florida (Lapointe et al. 2004), but a clear pattern of nutrient loading that promotes Synechococcus blooms in Florida Bay has not emerged (Phlips et al. 1999, Glibert et al. 2004, Goleski et al. 2010). In shallow, well-mixed systems such as Florida Bay, benthic suspension feeders such as bivalves or sponges can exert top-down control on phytoplankton (Officer et al. 1982). Dense sponge communities can pump water at rates sufficient to rapidly turn over entire water column volumes (Reiswig 1974) and can deplete near-bottom waters of picoplankton (Reiswig 1971a, Pile et al. 1997, Yahel et al. 2003). Cyanobacterial blooms in Florida Bay, perhaps combined with other environmental factors, seem to have disrupted pelagic (Goleski et al. 2010) and possibly benthic (Peterson et al. 2006) grazing in Florida Bay. Peterson et al. (2006) found that sponge mortality in the north-central region of Florida Bay increased water column turnover time by sponge filtration from $3 \mathrm{~d}$ to $15 \mathrm{~d}$, and this region of Florida Bay has experienced the most dense and persistent cyanobacterial blooms (Phlips et al. 1999, Goleski et al. 2010). To date, no study has considered how in situ changes in cyanobacteria blooms affect sponge populations in Florida Bay.

In this study, we sought to measure the effect of cyanobacterial blooms on the filtration and survival of loggerhead sponges Spheciospongia vesparium in Florida Bay. We measured the survival of $S$. vesparium in regions of Florida Bay with and without cyanobacterial blooms. Through the InEx technique, we were able to separately measure water pumping rates and particle retention (Yahel et al. 2005) of suspension feeding sponges. The second objective was to use measured in situ filtration rates of loggerhead sponges under both bloom and non-bloom conditions to determine whether sponges exert significant top-down control on cyanobacterial blooms in this shallow, sub-tropical lagoon. 


\section{MATERIALS AND METHODS}

\section{Study sites}

Six study sites were sampled across Florida Bay to cover a range of bloom densities and geographic areas (Fig. 1). These sites were Man $\mathrm{O}^{\prime}$ War Key $\left(25^{\circ}\right.$ $\left.01.562^{\prime} \mathrm{N}, 80^{\circ} 55.764^{\prime} \mathrm{W}\right)$, Barnes Key $\left(24^{\circ} 58.442^{\prime} \mathrm{N}\right.$, $\left.80^{\circ} 48.279^{\prime} \mathrm{W}\right)$, Samphire Keys $\left(25^{\circ} 06.478^{\prime} \mathrm{N}\right.$, $80^{\circ}$ $\left.43.341^{\prime} \mathrm{W}\right)$, Twin Key $\left(24^{\circ} 57.086^{\prime} \mathrm{N}, 80^{\circ} 43.865^{\prime} \mathrm{W}\right)$, Park Key $\left(25^{\circ} 06.993^{\prime} \mathrm{N}, 80^{\circ} 32.178^{\prime} \mathrm{W}\right)$, and Duck Key $\left(25^{\circ} 10.501^{\prime} \mathrm{N}, 80^{\circ} 29.270^{\prime} \mathrm{W}\right)$. These study sites were visited 5 times over a 1 yr period: 17 to 30 July 2006; 6 to 11 November 2006; 8 to 15 January 2007; 31 March to 6 April 2007; and 1 to 7 June 2007. Study sites were re-visited to survey water pumping rates from 7 to 15 December 2007.

\section{Measurements of cyanobacteria}

Measurements of temperature, salinity, and dissolved oxygen were made at each site and time- point using a YSI-556 probe. Chlorophyll a $(\mathrm{chl} a)$ was measured using glass fiber filters and standard fluorometric analysis (Parsons et al. 1984). To enumerate picoplankton, water samples were fixed in $1 \%$ formalin in the field, and kept refrigerated until they could be flash-frozen in liquid $\mathrm{N}_{2}$, always within $3 \mathrm{~d}$ after sampling. Abundance of heterotrophic bacteria (stained with SYBR Green I), picocyanobacteria, and photosynthetic picoeukaryotes were determined on a FACSort (Becton-Dickinson) flow cytometer using fluorescence patterns and particle size from side angle light scatter (Olson et al. 1991). A minimum of 3 samples were taken for chl $a$ and picoplankton enumeration at each site and time-point. Water quality measurements were analyzed with a Spearman rank-order correlation using the software SigmaStat 3.5. This correlation analysis was performed once with all sites and time-points pooled, and again with the data separated by time-point to avoid temporal pseudoreplication. A 'bloom threshold' of $350 \times 10^{3}$ cyanobacterial cells $\mathrm{ml}^{-1}$ (Phlips et al. 1999, Goleski et al. 2010) was used to classify each site at each time

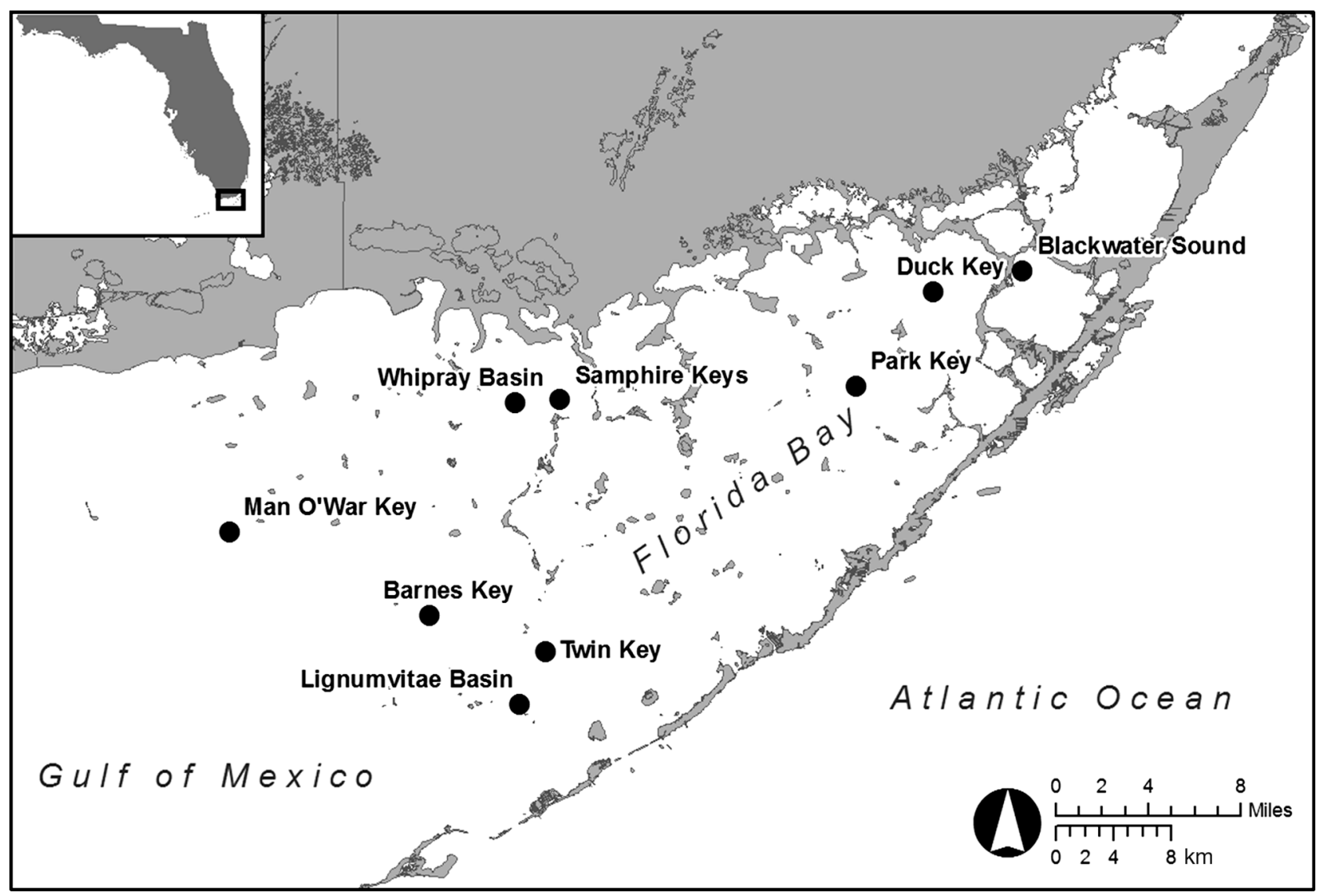

Fig. 1. Locations of study sites in Florida Bay, USA. Study sites are named by the nearest mangrove key. Inset shows the location of Florida Bay, FL, USA 
point as 'bloom' or 'non-bloom.' Cyanobacteria densities during intervals between time-points were modeled as simple exponential growth or decline, and these modeled densities were used to classify the intervals between time-points as 'bloom' or 'non-bloom.'

\section{Sponge survival}

Loggerhead sponges were the focus of this study as they are the largest and most abundant sponge in Florida Bay (Peterson et al. 2006, C. Wall pers. obs). Loggerhead sponges (1 to 31 biovolume) were collected from sites in and around Lignumvitae Basin $\left(24^{\circ} 54.8^{\prime} \mathrm{N}, 080^{\circ} 44.5^{\prime} \mathrm{W}\right.$; Fig. 1), which hosted bloomfree water and abundant sponges at the beginning of the study. Sponges were removed from the bottom and grown onto marked bricks for $\sim 5 \mathrm{~d}$ following the methods of Peterson et al. (2006). After attachment, sponges were rapidly transported in opaque vessels filled with seawater and transplanted $(\mathrm{n}=4)$ to each study site, and survival of transplanted sponges at each sampling time was recorded. Transplanted sponges were replaced as needed to maintain a sample size of 4 individuals at each site. The frequencies of live and dead sponges were tested for heterogeneity between sites using a chi-squared test (Zar 1998). The frequencies of live and dead transplanted sponges were further analyzed using a $G$-test of independence to compare frequencies of live/dead after bloom and non-bloom periods (Sokal \& Rohlf 1995, Zar 1998). Since naturally-occurring sponges were not surveyed for mortality, the survival of transplanted sponges should be taken as an indicator of relative survival among sites and bloom vs. nonbloom periods.

\section{Filtration and particle retention}

To measure in situ filtration rates of naturallyoccurring and transplanted sponges, the 'InEx' method of Yahel et al. $(2003,2005)$ was employed. This method has been used to successfully measure filtration rates of several suspension feeders that have discrete siphons or oscula, such as sponges, bivalves, and solitary tunicates (Yahel et al. 2005). The InEx method consists of 2 techniques that separately measure pumping rate and particle retention. To measure pumping rates, small plastic tubes ( 0.8 to $1.2 \mathrm{~cm}$ internal diameter, 16 to $22 \mathrm{~cm}$ length) loaded with a small amount of fluorescein dye were placed just above an osculum of an actively pumping sponge. Since resistance in InEx tubes was likely inversely proportional to cross-sectional tube area (Vogel, 1994), use of smaller tubes for smaller oscula may have underestimated the pumping rates of these oscula. Using an underwater video camera and/or stopwatch, the time for the pumping action of the sponge to eject dye from the tube was measured, yielding the 'dye front speed.' This measurement was made at least 3 times over 3 different oscula of each sponge. Dye front speed multiplied by the cross-sectional area of the tube provides a water pumping rate in $\mathrm{ml} \mathrm{s}^{-1}$ osculum $^{-1}$, which was then scaled to $1 \mathrm{~s}^{-1}$ ind. ${ }^{-1}$ by multiplying by the number of oscula per individual; rates were further normalized to sponge volume $\left(\mathrm{l} \mathrm{s}^{-1} \mathrm{l}^{-1}\right.$ sponge biovolume) using direct measurements (volume displacement) or estimates based on dimensions (height and diameter, assuming cylindrical geometry). Pumping rate measurements were also made over bricks as a control for ambient water motion. Extreme light extinction during some micro-algal blooms prohibited measurement of pumping rates on some occasions; for sites with very high bloom densities (see Fig. 2, Man O'War Key and Samphire Keys) no live sponges were present and hence only transplanted sponges were measured.

Loggerhead sponges Spheciospongia vesparium measured in this study typically had 50 to 100 oscula with diameters ranging from 0.5 to $1.5 \mathrm{~cm}$ (C. Wall \& B. Peterson pers. obs.). While every effort was made to match the diameters of the dye-front tubes to the diameters of the oscula (Yahel et al. 2005), it is possible that these measurements underestimated some water pumping rates due to restricted flow through the dye-front tubes. There was not sufficient coverage of water pumping data to permit site and timepoint comparisons. Instead, these data were pooled according to transplant status and bloom condition, and analyzed with a 2-way ANOVA using natural vs. transplant and bloom vs. non-bloom as the 2 variance factors. Water pumping rates ( $\log _{10}$-transformed) were then regressed on cyanobacteria density $\left(\log _{10^{-}}\right.$ transformed), and the regression slopes of the water pumping rates of natural and transplanted sponges vs. cyanobacteria density were compared using an analysis of covariance (ANCOVA). Water pumping rates were further regressed on cyanobacteria density, temperature, and salinity using a forward stepwise multiple linear regression using the software SPSS-PASW 18. Since the mortality of sponges in bloom-prone regions limited sample sizes during some time points for some locations, this multiple- 
regression equation was then used to hindcast water pumping rates for sites and dates where no water pumping rates were available. Hindcasted water pumping rates were used to estimate the magnitude of basin-wide grazing rates by loggerhead sponges (see below). The hindcasted data were not used in any direct statistical comparisons with measured water pumping rates.

Particle retention by sponges was measured by obtaining small volumes of inhaled and exhaled water (Yahel et al. 2003, 2005) in small plastic tubes (approx. $10 \mathrm{ml}$ ) with re-sealable caps. The 'inhaled' sample was obtained from the ambient water around the sponge using a syringe to draw water into the 'In' tube, while the exhaled sample was captured by placing the ' $E x^{\prime}$ ' tube just above the sponge's osculum. The 'Ex' tube was held in place for double the dye-flushing time, usually 10 to $20 \mathrm{~s}$. Both tubes were immediately capped underwater after obtaining the sample. Paired inhaled-exhaled samples were replicated 3 times per sponge, and at least 3 sponges were sampled per site per time point. The inhaled and exhaled samples were fixed in the field with a $1 \%$ formalin solution, and kept refrigerated until they could be flash-frozen in liquid $\mathrm{N}_{2}$, always within $3 \mathrm{~d}$ after sampling. Abundance of heterotrophic bacteria (stained with SYBR Green I), picocyanobacteria, and photosynthetic picoeukaryotes were determined on a FACSort (Becton-Dickinson) flow cytometer using fluorescence patterns and particle size from side angle light scatter (Olson et al. 1991).

Inhaled and exhaled samples of chl a were also obtained, using a modified InEx method to obtain larger sample volumes ( $\geq 60 \mathrm{ml}$ ). Inhaled chl a samples were taken from ambient water with a syringe, while exhaled chl a samples were taken from pumping sponges using intravenous drip bags. These flexible, plastic bags were fitted with $1 \mathrm{~cm}$ diameter Tygon tubing that was placed over an approx. $1 \mathrm{~cm}$ osculum of the pumping sponge; the tubing was held in place for 1 to $2 \mathrm{~min}$, typically ensuring $\geq 60 \mathrm{ml}$ of water was collected. These samples were only retained if the sponge pumped enough water to visibly inflate the bag. Triplicate inhaled and exhaled bags per sponge were sealed underwater, and then kept cool and dark until the water could be filtered through GF/F filters, always within $2 \mathrm{~h}$. The filters were frozen and analyzed for chl a using standard fluorometric procedures (Parsons et al. 1984).

Paired 'In' and 'Ex' samples were used to calculate retention efficiencies for $\mathrm{chl} a$ and the various cell populations using the equation:

\section{Retention efficiency $=100([\mathrm{In}]-[\mathrm{Ex}]) /[\mathrm{In}]$}

Where '[In]' is the inhaled concentration and '[Ex]' is the exhaled concentration. The means of the 'In' samples were used for total ambient cell concentrations at each site and each time point. Retention efficiencies were analyzed using a Spearman's rank correlation with cyanobacteria density, chl $a$, temperature, and salinity. Sponge filtration of chl a by sponges was calculated using:

Filtration rate $=$ water pumping rate $([\mathrm{In}]-[\mathrm{Ex}])$

Filtration rates calculated as above have the units of $\mu \mathrm{g}$ chl a removed per day per ml sponge biovolume. Water pumping rates and InEx samples were paired for individual sponges. On occasions where InEx samples but no water pumping rates had been obtained, a water pumping rate for that site and time point was hindcasted using a multiple regression of water pumping rate on cyanobacteria density, temperature, and salinity. These hindcasted values for pumping rate were then combined with measured cell or chl a retention to calculate the filtration rate. Filtration rates were compared between bloom and non-bloom conditions using a 2-way ANOVA with bloom vs. non-bloom and natural vs. transplanted as the 2 variance factors. Cyanobacterial cell densities, sponge water pumping rates, sponge retention efficiencies, and sponge survival were measured for 3 or more individual sponges per site per time-point. While we did not capture variation on a shorter (h to wk) time scale, our measurements provide 'snapshots' that reflect longer-term variation in cyanobacteria blooms and sponge activity.

\section{Estimating the impact of sponge grazing on cyanobacteria blooms in Florida Bay}

Biovolume-specific filtration rates of sponges (cells consumed $\mathrm{s}^{-1} \mathrm{ml}$ sponge $\mathrm{e}^{-1}$ ) were scaled to basinwide filtration rates (cells consumed $\mathrm{d}^{-1} \mathrm{~m}^{-2}$ ) using the natural abundances (biomass $\mathrm{m}^{-2}$ ) of loggerhead sponges in Florida Bay and the relationship between biomass and biovolume of loggerhead sponges in Florida Bay (Peterson et al. 2006). These basin-wide filtration rates were divided by the mean number of cells present in the water column for each basin to produce an instantaneous grazing rate $\left(\mathrm{d}^{-1}\right)$, akin to a zooplankton grazing rate (Calbet \& Landry 2004). Florida Bay is a shallow ( $1 \mathrm{~m}$ ) and well-mixed ecosystem (Nuttle et al. 2000), and thus we assume sponges have access to the entire water column. Although 
Spheciospongia vesparium is known to pump strongly and continuously on a scale of hours (Peterson et al. 2006, Weisz et al. 2008), some species change water pumping behavior on diel or over longer time scales (Reiswig 1971b). Since no study to date has examined the water pumping behavior of $S$. vesparium on longer time scales, for the purposes of this calculation, sponges were assumed to pump continuously. Sponge grazing rates were then compared to the cyanobacteria growth rates as measured by Goleski et al. (2010) concurrently at all sites and time-points during this study to estimate net cyanobacterial growth or decline per basin and per time point as a function of sponge grazing and cyanobacterial cellular growth.

\section{RESULTS}

\section{Bloom dynamics}

Cyanobacterial densities (Fig. 2) varied widely between sites, with the maximum bloom densities occurring in the north-central and southwestern regions of the bay. Of the 6 sites visited, 4 had cyanobacteria blooms with cell densities above $350 \times$ $10^{3}$ cells $\mathrm{ml}^{-1}$ (Fig. 2). Three of those sites were in the north-central and southwestern regions of Florida Bay: Samphire Keys, Barnes Key, and Man O'War Key; these sites had blooms $>10^{6}$ cells $\mathrm{ml}^{-1}$, which were similar to blooms described in previous studies (Phlips et al. 1999, Glibert et al. 2004, Goleski et al. 2010). The fourth site was Duck Key in the northeast

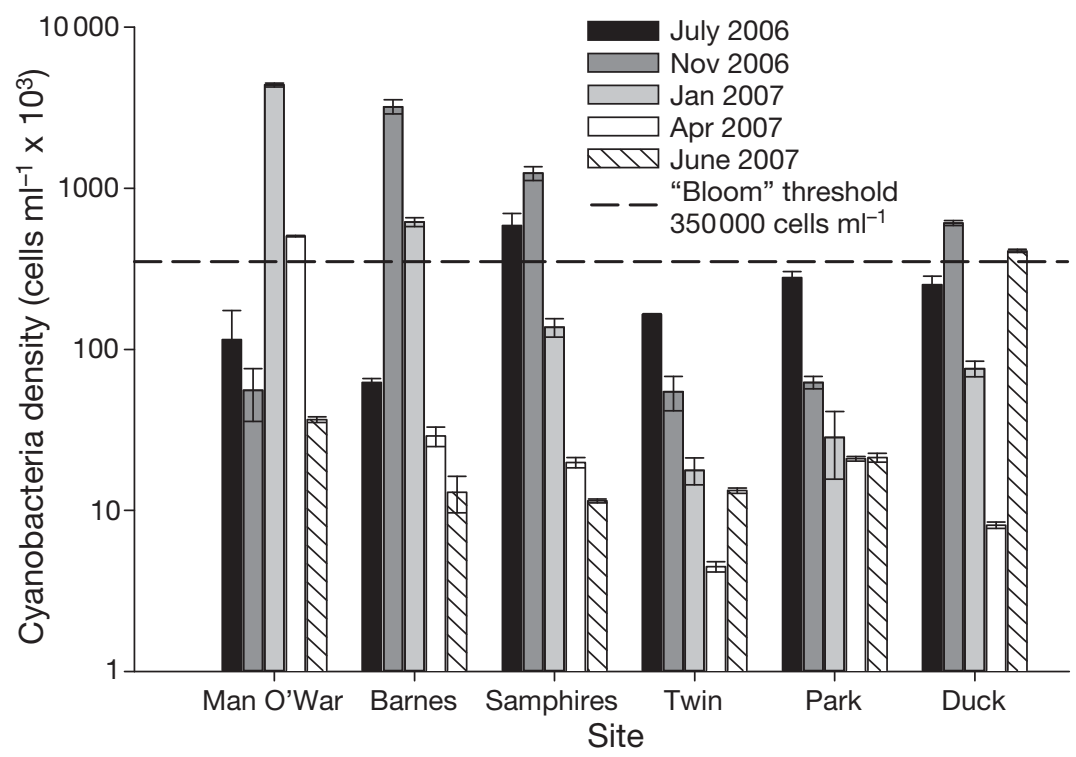

Fig. 2: Cyanobacteria densities at Florida Bay study sites, 2006 and 2007. Values are mean $\pm \mathrm{SE}$ region of the bay, which was not reported to have blooms in prior studies. The 2 remaining sites, Twin Keys (southern region) and Park Key (northeastern region) had low densities of cyanobacteria throughout the study, ranging from 4.5 to $280 \times 10^{3}$ cells ml $^{-1}$; Fig. 2). Levels of chl a were strongly positively correlated with cyanobacteria densities across all sites and dates $(\mathrm{r}=0.619, \mathrm{p}<0.001$, Spearman's rank correlation). Cyanobacteria densities were not correlated with temperature or salinity in the pooled dataset. When separated by time-point, cyanobacteria densities were still positively correlated with chl a levels on 4 out of 5 time-points (Nov 2006, Jan 2007, Apr 2007, and Jun 2007) with r-values ranging from 0.737 to 0.894 . Cyanobacteria density was positively correlated with salinity on one occasion (July 2006, r = $0.780, p<0.05)$, negatively correlated with salinity at one other time-point (June 2007, $r=-0.886, p<0.05$ ), and was not correlated with temperature at any of the separate time-points.

Temperatures were maximal in July 2006, ranging from 28.6 to $30.9^{\circ} \mathrm{C}$, declined from November 2006 (23.1 to $25.1^{\circ} \mathrm{C}$ ) through January 2007 (18.2 to $20.8^{\circ} \mathrm{C}$ ), and began to rise again from April (22.8 to $25.4^{\circ} \mathrm{C}$ ) through June 2007 (27.5 to $29.1^{\circ} \mathrm{C}$ ). Salinities were variable (30.0 to 39.7 ) across sites and dates. Salinities were highest in June 2007 (37.9 \pm 0.5, mean $\pm \mathrm{SE}$ ) and lowest in November 2006 (33.9 \pm 1.4). Salinity was not significantly correlated with temperature, chl $a$, or cyanobacteria densities.

\section{Sponge survival}

The survival of transplanted loggerheads among sites ranged from 36 to $100 \%$. Survival rates were $50 \%$ at Man O'War Key, $83 \%$ at Barnes Key, $36 \%$ at Samphire Keys, $57 \%$ at Park Key, and $100 \%$ at Duck Key, but survival was was not significantly different by site $\left(\chi^{2}=7.43\right.$, df $\left.=4, \mathrm{p}>0.05\right)$. Transplanted sponges at the Twin Keys site were not included because they could not be completely recovered at each time-point. Survival of transplanted sponges differed by bloom vs. non-bloom conditions ( $G=$ 6.06 , df $=1, \mathrm{p}<0.05$ ). Sponge survival was significantly higher following non-bloom conditions $(71 \%)$ than following bloom conditions (33\%) across all sites and dates. 


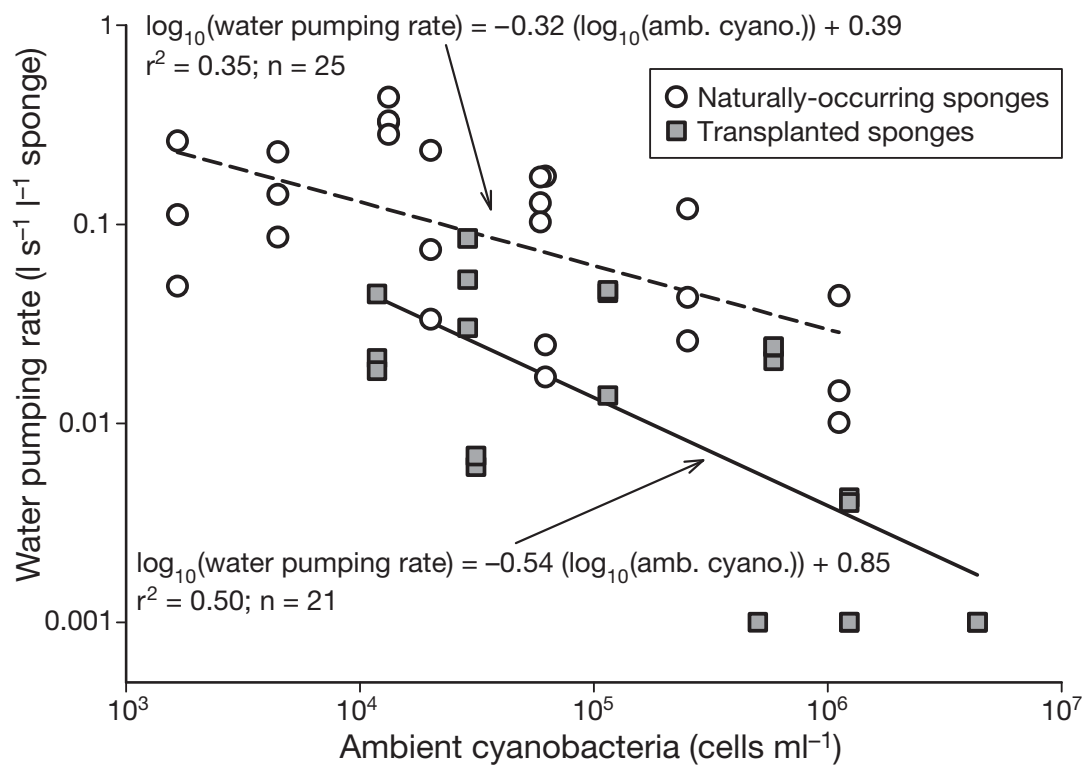

Fig. 3. Spheciospongia vesparium. Measured water pumping rates of natural and transplanted sponges. Water pumping rates $(n=46)$ of loggerhead sponges normalized to sponge biovolume $\left(\mathrm{l} \mathrm{s}^{-1} \mathrm{l}^{-1}\right.$ sponge tissue) across the range of observed cyanobacteria densities. Slopes of the regressions are significantly different $(p<0.001$, ANCOVA)

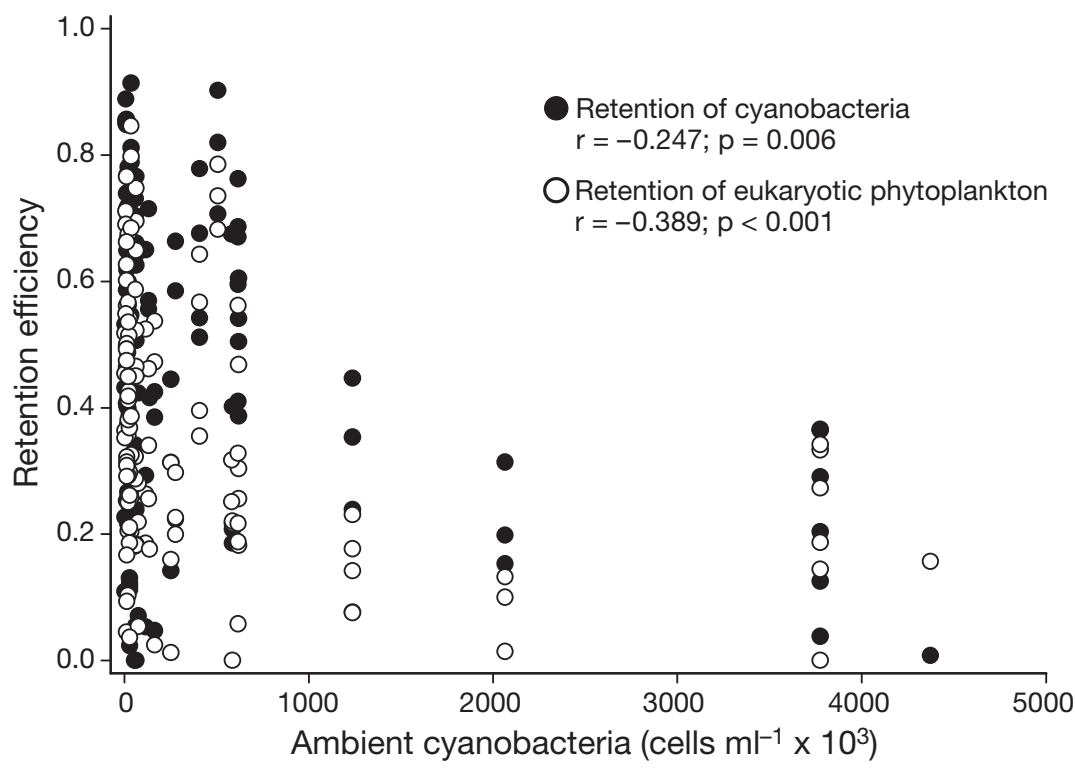

Fig. 4. Spheciospongia vesparium. Retention efficiencies. Retention of cyanobacteria and eukaryotic phytoplankton by loggerhead sponges vs. ambient cyanobacteria density ( $\mathrm{n}=123$ for cyanobacteria retention, $\mathrm{n}=120$ for eukaryotic phytoplankton retention)

ANOVA), and there was a strong negative correlation between sponge water pumping rates and cyanobacteria densities for both natural and transplanted sponges (Fig. $3 ; \mathrm{r}=-0.706$ for transplants, $\mathrm{r}=-0.590$ for natural sponges; $\mathrm{p}<0.05$, Spearman's rank correlation). Over the whole study, the water pumping rates of natural sponges were significantly higher $\left(0.139 \pm 0.024 \mathrm{l} \mathrm{s}^{-1} \mathrm{l}^{-1}\right)$ than those of transplanted sponges $\left(0.022 \pm 0.005 \mathrm{l} \mathrm{s}^{-1} \mathrm{l}^{-1}\right.$; $F_{1,42}=16.11, \mathrm{p}<0.001,2$-way ANOVA). Barnes Key and Twin Key were the only sites for which water pumping rates were available for both natural and transplanted sponges over multiple timepoints. Under non-bloom conditions, measured water pumping rates for natural and transplanted sponges at these 2 sites were similar ( $p>0.05$, Mann-Whitney $U$-test). The log-transformed water pumping rates of both natural and transplanted sponges were negatively correlated with cyanobacteria density (Fig. 3); however transplanted sponges had much more negative response (slope $=-0.543$ ) than natural sponges (slope $=-0.320$ ) with cyanobacteria density (slopes different at $\mathrm{p}<0.001$, ANCOVA).

Water pumping rates of natural sponges were partially explained by a multiple linear regression on cyanobacterial densities and salinity (S) according to the following equation:

$$
\begin{gathered}
\log _{10}(\text { pumping rate })=-0.432 \times \log _{10} \\
(\text { cyanobacteria density }) \\
+0.042 \mathrm{~S}-0.479
\end{gathered}
$$

This regression explained $49 \%$ of the variance in $\log _{10}$ (pumping rates) where pumping rate is expressed in $1 \mathrm{~s}^{-1} \mathrm{l}^{-1}$ and cyanobacteria density is expressed in cells $\mathrm{ml}^{-1}\left(\mathrm{r}^{2}=0.49, \mathrm{n}=25, \mathrm{p}<0.001\right)$.

\section{Retention efficiencies}

\section{Water pumping rates}

The water pumping rates of sponges under nonbloom conditions were significantly higher $(0.114 \pm$ $\left.0.019 \mathrm{l} \mathrm{s}^{-1} \mathrm{l}^{-1}\right)$ than sponges under bloom conditions $\left(0.012 \pm 0.004 \mathrm{l} \mathrm{s}^{-1} \mathrm{l}^{-1} ; F_{1,42}=23.17, \mathrm{p}<0.001,2\right.$-way
The retention efficiency of particles by loggerhead sponges varied by cyanobacterial cell abundance, site, and date. Loggerhead sponges had a mean \pm SE cyanobacteria retention of $46 \pm 2.2 \%$, while the eukaryotic phytoplankton retention was $36 \pm 1.8 \%$, the bacteria retention was $40 \pm 1.7 \%$, and the chl a reten- 
tion was $35 \pm 1.9 \%$. The retention of cyanobacteria and eukaryotic phytoplankton by sponges were both negatively correlated with ambient densities of cyanobacteria (Fig. 4; r $=-0.247, \mathrm{p}<0.01$ for cyanobacteria retention; $\mathrm{r}=-0.389$, $\mathrm{p}<0.001$ for eukaryotic cell retention; Spearman's rank correlation). The retention of bacteria and cyanobacteria by sponges was weakly correlated with salinity $(r=0.186$ and 0.183, p < 0.05, Spearman's rank correlation) but was not correlated with any of the other variables.

\section{Chlorophyll a filtration rates}

Chl a filtration rates were generally higher for natural sponges compared to transplanted individuals (Fig. 5). For both types of sponges, chl a filtration rates under non-bloom conditions were significantly higher than filtration rates for sponges under bloom conditions (Fig. $5 ; F_{1,97}=5.10, \mathrm{p}<0.05$ ). The mean biovolume-specific chl a filtration of transplanted sponges under bloom conditions was $0.39 \pm 0.20 \mu \mathrm{g}$ chl a d $\mathrm{d}^{-1} \mathrm{ml}^{-1}$, while the chl a filtration of transplanted sponges under non-bloom conditions was $1.75 \pm$

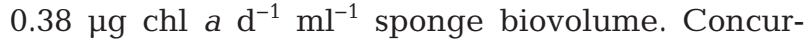
rently, the chl a filtration of natural sponges under bloom conditions was $1.18 \pm 0.30 \mu \mathrm{g} \mathrm{chl} \mathrm{a} \mathrm{d} \mathrm{d}^{-1} \mathrm{ml}^{-1}$, while the chl a filtration of natural sponges under non-bloom conditions was $2.97 \pm 0.58 \mu \mathrm{g} \operatorname{chl~a~d} \mathrm{d}^{-1}$

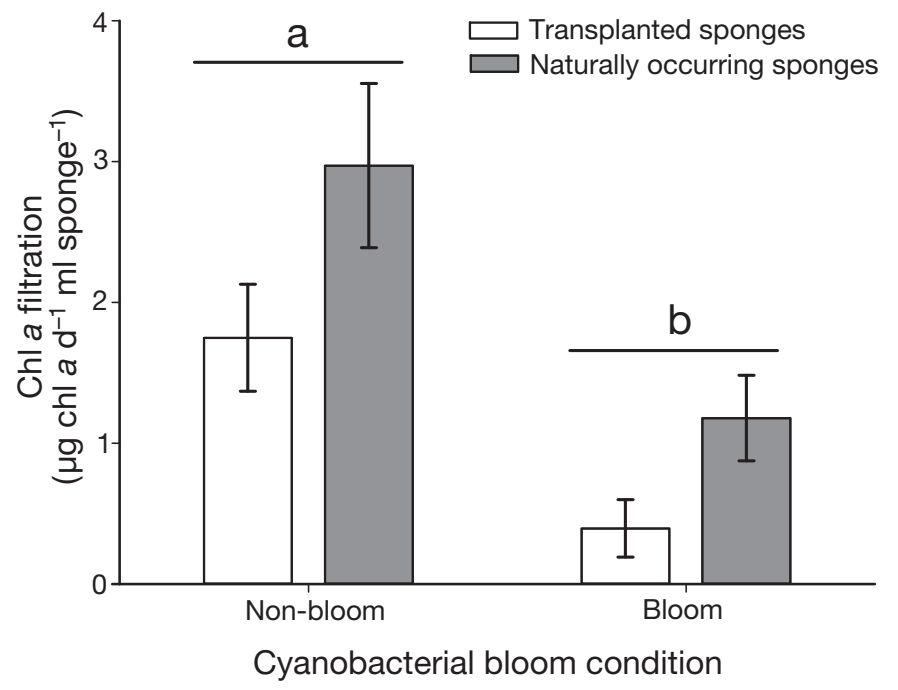

Fig. 5. Spheciospongia vesparium. Comparison of chl a filtration rates under bloom and non-bloom conditions by transplanted and naturally occurring loggerhead sponges $(n=101)$. A cyanobacteria density of $350 \times 10^{3}$ cells ml $^{-1}$ was used as the threshold for bloom vs. non-bloom conditions. Different letters above bars indicate significant difference. Values are mean $\pm \mathrm{SE}$ $\mathrm{ml}^{-1}$. Chl a filtration rates were negatively correlated with cyanobacteria density $(\mathrm{r}=-0.463, \mathrm{p}<0.001$, Spearman's rank correlation) and were positively correlated with salinity $(\mathrm{r}=0.341, \mathrm{p}<0.001)$.

\section{Net growth rates of cyanobacteria as a function of sponge filtration}

Since there was a difference in measured pumping rates of natural vs. transplanted sponges, and this difference may have been biased by the lack of naturally-occurring sponges in bloom areas, measured pumping rates only for naturally occurring sponges were used to assess the potential basin-wide impacts of sponges on cyanobacteria. Pumping rates for transplanted sponges were hindcasted based on cyanobacteria density and salinity using the regression in 'Water pumping rates'. For this analysis, biovolume-based pumping rates were converted to biomass-based rates using $0.24 \mathrm{~g} \mathrm{DW} \mathrm{ml}^{-1}$ biovolume (Peterson et al. 2006). These biomass-based water pumping and cell removal rates were scaled to basin-wide rates using Peterson et al.'s (2006) surveys of sponge biomass in Florida Bay.

Estimated net growth rates of cyanobacteria varied from positive to negative across Florida Bay (results from Goleski et al. 2010) (Fig. 6). The mean of intrinsic cyanobacterial cellular growth across all sites and dates was $1.08 \pm 0.21 \mathrm{~d}^{-1}$, and ranged from $0.45 \pm$ $0.15 \mathrm{~d}^{-1}$ at Duck Key to $1.81 \pm 1.27 \mathrm{~d}^{-1}$ at Barnes Key (Fig. 6). Since no growth rate data were available for Man O' War Key, the universal mean of the Goleski et al. (2010) data $\left(1.08 \pm 0.21 \mathrm{~d}^{-1}\right)$ was used for that site. These cellular growth rates are consistent with those previously reported for laboratory cultures of Synechococcus sp. (Kana \& Glibert 1987), the genus of cyanobacteria which blooms in Florida Bay (Phlips et al. 1999). The mean grazing or removal rate of cyanobacteria by loggerhead sponges across all sites was $0.54 \pm 0.10 \mathrm{~d}^{-1}$, and ranged from $0.15 \pm 0.09 \mathrm{~d}^{-1}$ at Samphire Keys to $0.79 \pm 0.22 \mathrm{~d}^{-1}$ at Park Key (Fig. 6). Cyanobacterial net growth rates were strongly positive (0.78 to $\left.1.45 \mathrm{~d}^{-1}\right)$ at Man $\mathrm{O}^{\prime}$ War Key, Samphire Keys, and Barnes Key, low (0.07 to $0.24 \mathrm{~d}^{-1}$ ) for Twin Keys and Park Key, and were negative $\left(-0.17 \mathrm{~d}^{-1}\right)$ for Duck Key (Fig. 6).

\section{DISCUSSION}

Over the course of a 1 yr field study (July 2006 to June 2007), we documented a cyanobacterial bloom 


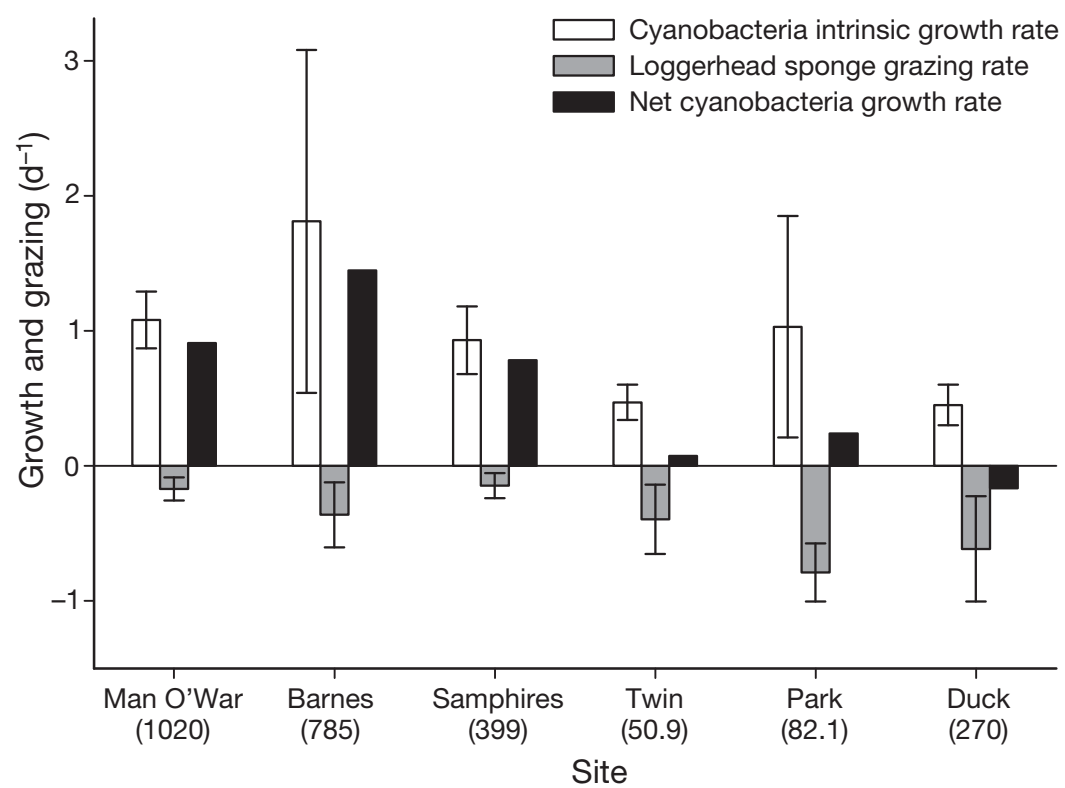

Fig. 6. Growth and grazing. Cyanobacteria growth rates $(\mathrm{n}=18)$, loggerhead sponge grazing rates ( $\mathrm{n}=5$ per site), and net cyanobacteria growth (growth minus grazing), averaged over all time-points for each site. Values of bars are mean \pm SE. Numbers below each site name are the mean annual cyanobacteria density for that site in cells $\mathrm{ml}^{-1} \times 10^{3}$

of the genus Synechococcus in north-central and western Florida Bay, with bloom densities ranging from $10^{5}$ to $10^{6}$ cells $\mathrm{ml}^{-1}$. Survival of transplanted loggerhead sponges decreased following blooms. In situ measurements of loggerhead sponge water pumping rates and retention efficiency of particles revealed that both measures declined in the presence of dense cyanobacterial blooms. The sponges' chl a-based filtration rates decreased nearly 4 -fold under bloom conditions. Finally, study sites with blooms $>10^{6}$ cells ml $^{-1}$ had net positive cyanobacteria growth rates averaged over the year, while the other sites had loggerhead grazing rates sufficient to limit or exceed cyanobacteria growth rates when averaged over the year. Together, these findings suggest that cyanobacterial blooms may be capable of depressing sponge populations and that dense communities of sponges may be capable of inducing topdown control of cyanobacteria.

The results of the present study suggest cyanobacterial blooms have a negative impact on Florida Bay's sponge community. Previous studies have found widespread sponge mortality coincident with or following cyanobacteria blooms in Florida Bay (Butler et al. 1995, Stevely \& Sweat 1998), but description of a mechanism has remained elusive (Lynch \& Phlips 2000). Extracellular polysaccharides or toxins associated with Synechococcus spp. cells in Florida Bay (Phlips et al. 1989, Lynch \& Phlips 2000, Carmichael
\& Li 2006) may have disrupted sponge filtration and retention by affecting the choanocyte cells which are responsible for feeding in sponges. These compounds have impaired the filtration of other suspension feeders (Rohrlack et al. 1999, Gainey \& Shumway 1991, Liu \& Buskey 2000) and thus may have contributed toward sponge mortality. Lynch \& Phlips (2000) did not find significant mortality of sponges exposed to natural and cultured Synechococcus spp. $\left(\sim 5 \times 10^{6}\right.$ cells ml $\left.{ }^{-1}\right)$ over a time scale of $5 \mathrm{~d}$, so it is reasonable to assume damage to sponges occurs over a longer time scale. In the present study, the survival of transplanted loggerhead sponges after bloom periods declined significantly compared to survival after nonbloom periods, on a time scale of $\sim 2$ mo. Although not included in the statistical analyses, all loggerhead sponges transplanted into Whipray Basin and Blackwater Sound perished within 4 mo during cyanobacteria blooms with densities of 1.5 to $2.4 \times 10^{6} \mathrm{cells} \mathrm{ml}^{-1}$. Monthly water quality records for the region around the Samphire Keys indicate that chl a levels were elevated for 5 mo during the fall-winter 2006/2007 period (SERC-FIU 2007). This region of the bay corresponds with the historical occurrence of cyanobacteria blooms (Phlips et al. 1999) and with the highest mortality of transplanted sponges in the present study. Although physical conditions could be the underlying drivers of sponge mortality, no correlations between sponge mortality and physical factors (temperature, salinity, dissolved oxygen) were found in this study.

Sponge pumping rates and retention efficiencies in Florida Bay were depressed in the presence of cyanobacteria blooms (Figs. 3 \& 4). Water pumping rates were significantly lower under bloom conditions, and there was a strong negative correlation between sponge water pumping rates and cyanobacteria cell density (Fig. 3) as well as the sponges' retention of cells and cyanobacteria density (Fig. 4). Sponge water pumping rates had a weak positive relationship with salinity over the range of salinities observed (30 to 39) and had no detectable relationship with temperature. Temperature and salinity are obvious criteria that structure the physiology of all marine organisms, but they seemingly play a small role relative to cyanobacteria densities in affecting the responses of sponges over the range of values that we measured in Florida Bay. Even though the 
pumping rates of natural and transplanted sponges were similar under non-bloom conditions at Barnes Key and Twin Key, there was a strong difference in how natural and transplanted sponges responded to bloom densities of cyanobacteria (Fig. 3). Hence, transplant stress may influence the vulnerability of sponges to harmful cyanobacteria blooms.

Most measurements of sponge feeding have been conducted in coral reef environments with clear water and relatively low particle loads (Reiswig 1974, Yahel et al. 2003, Weisz et al. 2008). Far fewer studies have been designed to understand how phytoplankton blooms affect sponge filtration within shallow coastal lagoons such as Florida Bay. The mean loggerhead sponge pumping rates in this study was $0.090 \pm 0.016 \mathrm{l} \mathrm{s}^{-1} 1$ sponge biovolume ${ }^{-1}$, which is comparable to values for the same species of $0.069 \mathrm{ml}$ $\mathrm{s}^{-1} \mathrm{ml}^{-1}$ reported by Lynch \& Phlips (2000), but lower than the values reported by Weisz et al. (2008) and Peterson et al. (2006) $\left(0.176 \mathrm{l} \mathrm{s}^{-1} \mathrm{l}^{-1}\right.$ and $0.230 \mathrm{l} \mathrm{s}^{-1} \mathrm{l}^{-1}$, respectively). The mean of pumping rates for loggerhead sponges under non-bloom conditions, was $0.113 \pm 0.014 \mathrm{l} \mathrm{s}^{-1} \mathrm{l}^{-1}$, which is closer to the value of $0.176 \mathrm{l} \mathrm{s}^{-1} \mathrm{l}^{-1}$ reported by Weisz et al. (2008) for the same species in a reef environment, suggesting cyanobacterial abundance may account for observed differences.

Loggerhead sponges in Florida Bay were able to retain substantial proportions of cyanobacteria (46 \pm $2.2 \%$ ) and other picoplankton that passed through their canal systems, but these values are much lower than has been reported for other sponges in coral reef and lake environments (Reiswig 1971a, Pile et al. 1997, Yahel et al. 2003) where retention efficiencies of 58 to $95 \%$ are common. There are undoubtedly inter-specific differences in retention efficiencies of sponges (Turon et al. 1997), but the low retention efficiencies in the present study are likely due to ambient particle densities. Yahel et al. (2003) measured Synechococcus spp. densities at $10^{3}$ to $10^{4}$ cells $\mathrm{ml}^{-1}$ in a coral reef environment, while the lagoonal system of Florida Bay had turbid waters and blooms of $10^{5}$ to $10^{6}$ cyanobacteria cells ml ${ }^{-1}$. The feeding requirements of loggerhead sponges in Florida Bay may have been saturated by dense ambient cell concentrations, which would not be observed in most reef environments. Alternatively, the decline in sponge water pumping, retention, and filtration could be due to substances produced by cyanobacteria cells that inhibit sponges as described (Phlips et al. 1989, Lynch \& Phlips 2000).

If sponges are retaining large numbers of cells in their canal systems without being able to ingest or process those particles, then the mechanism of damage to sponges may be clogging of the canal system by cyanobacteria (Duckworth et al. 2003), which forces the sponges to shut down their water pumping activities. This would explain the damage caused by blooms to sponge communities (Lynch \& Phlips 2000) as reflected in the higher sponge mortality observed during some blooms in Florida Bay. High particle concentrations have been shown to decrease the growth of the sponge Axinella corrugata in a laboratory experiment (Duckworth et al. 2003). Little is known about the particle selection ability of sponges; although bivalve suspension feeders are known to pre-ingestively reject particles as a way of dealing with high particle loads (Hawkins et al. 1996, Ward et al. 1998). In addition to high particle loads, cyanobacteria blooms may be a poor food source. Studies of suspension feeder nutritional requirements have found that a phytoplankton community dominated by picoplankton may be nutritionally deficient for bivalves (Bass et al. 1990) and sponges (Duckworth \& Pomponi 2005). Harmful algal blooms in temperate environments have been known to suppress the water pumping activity of many suspension feeders (Shumway 1990, Sunda et al. 2006), through a combination of high particle load, poor nutritive quality of particles, and active toxic effects of the algae.

There was a strong decrease in the water pumping rates of transplanted sponges compared to natural sponges, and this difference was present, but marginally non-significant $(p<0.10)$ for chl $a$-based filtration rates. This suggests that transplanted sponges may have a lower filtration capacity in areas of Florida Bay affected by cyanobacteria blooms. Some bivalve suspension feeders have been known to adapt or acclimate to harmful algal blooms (Bricelj et al. 2005, Hegaret et al. 2007). The water pumping rates of natural and transplanted sponges were both negatively correlated with cyanobacteria density (Fig. 3), but this negative correlation was much stronger for transplanted sponges (slope $=-0.54 ; \mathrm{r}=$ $-0.706, \mathrm{p}<0.05$, Spearman's rank correlation) than for naturally-occurring sponges (slope $=-0.32 ; \mathrm{r}=$ $-0.590, p<0.05$ ). The regressions of $\log _{10}$ (pumping rate) vs. $\log _{10}$ (cyanobacteria density) had significantly different slopes for transplanted and natural sponges $(p<0.001$, ANCOVA). Since the water pumping rates of natural sponges were less negatively affected by cyanobacteria densities, this may reflect an acclimation or adaptation on the part of the loggerhead sponge community that previously had been exposed to blooms, especially since transplanted sponges were harvested from a bloom-free 
area (Figs. 1 \& 2) and were therefore 'naïve' with respect to cyanobacterial blooms. Another hypothesis is that the transplanted sponges were stressed or damaged by the transplantation process and were not able to fully recover their water pumping functions. There are very few studies of the long-term responses of sponges to high particle loads or harmful algal blooms, so the degree to which sponges in affected regions of Florida Bay can adapt to and recover from persistent cyanobacterial blooms remains an open question.

The loss of sponge community in Florida Bay could explain the persistence of cyanobacteria blooms (Peterson et al. 2006) in the absence of clear trends in nutrients that promote blooms (Glibert et al. 2004, Goleski et al. 2010). Peterson et al. (2006) calculated that the sponge filtration time of the north-central region's water column was $3 \mathrm{~d}$ before the mortality event, and increased to $15 \mathrm{~d}$ afterwards, which corresponds to a turnover of $0.07 \mathrm{~d}^{-1}$. This is consistent with our study, where we found that cyanobacteria intrinsic growth rates were $\sim 1 \mathrm{~d}^{-1}$, and loggerhead sponge grazing rates on cyanobacteria ranged from $0.15 \mathrm{~d}^{-1}$ at Samphire Keys in the bloom-prone northcentral region to $0.79 \mathrm{~d}^{-1}$ at Park Key in a bloom-free northeastern region (Figs. $1 \& 6$ ). The 3 sites in our study that lie along the bloom-prone 'north-central to southwestern axis' identified by Phlips et al. (1999) all had blooms $>10^{6}$ cells $\mathrm{ml}^{-1}$, and all had loggerhead sponge community grazing rates insufficient to keep pace with cyanobacteria growth rates (Figs. 1 \& $6)$. The other 3 study sites, which either had no blooms or intermittent and small blooms $\left(<10^{6}\right.$ cells $\mathrm{ml}^{-1}$; Fig. 2) all had loggerhead sponge community grazing rates sufficient to limit or outpace cyanobacteria growth rates when averaged over the year (Fig. 6), and the sponge community grazing rate would be even higher if other sponge species were included (Peterson et al. 2006). While our calculations assumed that sponges were filtering all of the time, it may be that sponges were only actively filtering for a portion of the day, a result that would decrease sponge grazing rates. On the other hand, our calculations did not account for grazing by zooplankton that would increase the ecosystem filtration of blooms and perhaps balance grazing not performed by sponges. Regardless, our results suggest that the lack of benthic suspension feeding contributes to the development and persistence of harmful cyanobacteria blooms in Florida Bay. The loss of benthic grazing represents a positive feedback for the cyanobacteria, where harmful blooms impair grazers, and the loss of grazing enables further growth of cyanobacteria (Sunda et al. 2006). Unfortunately, this positive feedback for the cyanobacteria is a 'death spiral' for sponges (Butler et al. 1995, this study), with resulting loss of ecosystem services provided by sponges (Bell 2008), and could eventually affect the entire benthic community (Chasar et al. 2005). This represents a 'chicken or egg' management dilemma: more ecosystem filtration from suspension feeders is required to control algal blooms and improve water quality (Officer et al. 1982, Cerco \& Noel 2007, Wall et al. 2008), but water quality must first be improved before successful restoration of sponges can be attempted (Johnston \& Clark 2007).

While the ultimate cause of ecological disturbances in Florida Bay remains unresolved (Fourqurean \& Robblee 1999), much of the focus in research and management has been on the altered hydrology in the upstream Everglades (Nuttle et al. 2000, Marshall et al. 2009) and subsequent changes in nutrient loading (Boyer et al. 1999, Glibert et al. 2004). Cyanobacterial blooms have been a persistent (Phlips et al. 1999) and damaging disturbance to the Florida Bay benthic community (Butler et al. 1995), and loss of benthic communities has been linked to estuarine decline world-wide (Lotze et al. 2006). While many studies of bottom-up factors (e.g. nutrient loading) have provided valuable information (Fourqurean et al. 1993, Phlips \& Badylak 1996, Rudnick et al. 1999, Glibert et al. 2004), this study demonstrates that restoration of sponge communities could be part of a successful strategy for control of cyanobacteria blooms in Florida Bay.

Acknowledgements. Many people helped with field and laboratory work, including F. Koch, J. Carroll, J. Goleski, T. Davis, and T. Hattenrath. A big thank you to T. Frankovich for help with project logistics, and another to G. Yahel for discussions about his InEx method. This manuscript was greatly improved by the suggestions of G. Lopez, E. Ward, R. Aller, A. Duckworth, and 3 anonymous reviews. This project was funded by NOAA's South Florida Project grant NA06NOS4780077

\section{LITERATURE CITED}

Anderson DM, Burkholder JM, Cochlan WP, Glibert PM and others (2008) Harmful algal blooms and eutrophication: examining linkages from selected coastal regions of the United States. Harmful Algae 8:39-53

Bass AE, Malouf RE, Shumway SE (1990) Growth of northern quahogs (Mercenaria mercenaria Linnaeus 1758) fed on picoplankton. J Shellfish Res 9:299-307

> Bell JJ (2008) The functional roles of marine sponges. Estuar Coast Shelf Sci 79:341-353

> Boyer JN, Fourqurean JW, Jones RD (1999) Seasonal and long-term trends in the water quality of Florida Bay (1989-1997). Estuaries 22:417-430 
Bricelj VM, Connell L, Konoki K, MacQuarrie SP, Scheuer T, Catterall WA, Trainer VL (2005) Sodium channel mutation leading to saxitoxin resistance in clams increases risk of PSP. Nature 434:763-767

Butler MJ, Hunt JH, Herrnkind WF, Childress MJ and others (1995) Cascading disturbances in Florida bay, USA: cyanobacteria blooms, sponge mortality, and implications for juvenile spiny lobsters Panulirus argus. Mar Ecol Prog Ser 129:119-125

> Calbet A, Landry MR (2004) Phytoplankton growth, microzooplankton grazing, and carbon cycling in marine systems. Limnol Oceanogr 49:51-57

> Carmichael WW, Li R (2006) Cyanobacteria toxins in the Salton Sea. Saline Syst 2:5-17

Cerco CF, Noel MR (2007) Can oyster restoration reverse cultural eutrophication in Chesapeake Bay? Estuaries Coasts 30:331-343

- Cerrato RM, Caron DA, Lonsdale DJ, Rose JM, Schaffner RA (2004) Effect of the northern quahog Mercenaria mercenaria on the development of blooms of the brown tide alga Aureococcus anophagefferens. Mar Ecol Prog Ser 281:93-108

> Chasar LC, Chanton JP, Koenig CC, Coleman FC (2005) Evaluating the effect of environmental disturbance on the trophic structure of Florida Bay, USA: multiple stable isotope analyses of contemporary and historical specimens. Limnol Oceanogr 50:1059-1072

> Cloern JE (2001) Our evolving conceptual model of the coastal eutrophication problem. Mar Ecol Prog Ser 210: 223-253

> Duckworth AR, Pomponi SA (2005) Relative importance of bacteria, microalgae and yeast for growth of the sponge Halichondria melanadocia (De Laubenfels, 1936): a laboratory study. J Exp Mar Biol Ecol 323:151-159

> Duckworth AR, Samples GA, Wright AE, Pomponi SA (2003) In vitro culture of the tropical sponge Axinella corrugata (Demospongiae): effect of food cell concentration on growth, clearance rate, and biosynthesis of stevensine. Mar Biotechnol 5:519-527

Fourqurean JW, Robblee MB (1999) Florida Bay: a history of recent ecological changes. Estuaries 22:345-357

Fourqurean JW, Jones RD, Zieman JC (1993) Processes influencing water column nutrient characteristics and phosphorus limitation of phytoplankton biomass in Florida Bay, FL, USA: inferences from spatial distributions. Estuar Coast Shelf Sci 36:295-314

- Gainey LF, Shumway SE (1991) The physiological effect of Aureococcus anophagefferens (brown tide) on the lateral cilia of bivalve mollusks. Biol Bull 181:298-306

Glibert PM, Heil CA, Hollander D, Revilla M, Hoare A, Alexander J, Murasko S (2004) Evidence for dissolved organic nitrogen and phosphorus uptake during a cyanobacterial bloom in Florida Bay. Mar Ecol Prog Ser 280: 73-83

> Gobler CJ, Lonsdale DJ, Boyer GL (2005) A review of the causes, effects, and potential management of harmful brown tide blooms caused by Aureococcus anophagefferens (Hargraves et Sieburth). Estuaries 28:726-749

Goleski JA, Koch F, Marcoval MA, Wall CC, Jochem FJ, Peterson BJ, Gobler CJ (2010) The role of zooplankton grazing and nutrient loading in the occurrence of harmful marine cyanobacterial blooms in Florida Bay, USA. Estuaries Coasts 33:1202-1215

Hallegraeff GM (1993) A review of harmful algal blooms and their apparent global increase. Phycologia 32:79-99
Hawkins AJS, Smith RFM, Bayne BL, Heral M (1996) Novel observations underlying the fast growth of suspensionfeeding shellfish in turbid environments: Mytilus edulis. Mar Ecol Prog Ser 131:179-190

$>$ Heck KL, Valentine JF (2007) The primacy of top-down effects in shallow benthic ecosystems. Estuaries Coasts 30:371-381

> Hegaret H, Wikfors GH, Shumway SE (2007) Diverse feeding responses of five species of bivalve mollusc when exposed to three species of harmful algae. J Shellfish Res 26:549-559

> Heisler J, Glibert PM, Burkholder JM, Anderson DM and others (2008) Eutrophication and harmful algal blooms: a scientific consensus. Harmful Algae 8:3-13

> Johnston EL, Clark GF (2007) Recipient environment more important than community composition in determining the success of an experimental sponge transplant. Restor Ecol 15:638-651

Kana TM, Glibert PM (1987) Effect of irradiances up to 2000 $\mu \mathrm{E} \mathrm{m}^{-2} \mathrm{~s}^{-1}$ on marine Synechococcus WH7803: I. Growth, pigmentation, and cell composition. Deep-Sea Res 34:479-495

> Lapointe BE, Barile PJ, Matzie WR (2004) Anthropogenic nutrient enrichment of seagrass and coral reef communities in the Lower Florida Keys: discrimination of local versus regional nitrogen sources. J Exp Mar Biol Ecol 308:23-58

> Liu HB, Buskey EJ (2000) The exopolymer secretions (EPS) layer surrounding Aureoumbra lagunensis cells affects growth, grazing, and behavior of protozoa. Limnol Oceanogr 45:1187-1191

Lotze HK, Lenihan HS, Bourque BJ, Bradbury RH and others (2006) Depletion, degradation, and recovery potential of estuaries and coastal seas. Science 312: 1806-1809

Lynch TC, Phlips EJ (2000) Filtration of the bloom-forming cyanobacteria Synechococcus by three sponge species from Florida Bay, USA. Bull Mar Sci 67:923-936

Marshall FE, Wingard GL, Pitts P (2009) A simulation of historic hydrology and salinity in Everglades National Park: coupling paleoecologic assemblage data with regression models. Estuaries Coasts 32:37-53

Newell RIE (1988) Ecological changes in Chesapeake Bay, are they the result of overharvesting the eastern oyster (Crassostrea virginica)? In: Lynch MP, Krome EC (eds) Understanding the estuary, Publ. 129. Chesapeake Research Consortium, Gloucester Point, VA (also available at www.vims.edu/GreyLit/crc129.pdf)

Nuttle WK, Fourqurean JW, Cosby BJ, Zieman JC, Robblee MB (2000) Influence of net freshwater supply on salinity in Florida Bay. Water Resour Res 36:1805-1822

Officer CB, Smayda TJ, Mann R (1982) Benthic filter feeding: a natural eutrophication control. Mar Ecol Prog Ser 9:203-210

Olson RJ, Zettler ER, Chisholm SW, Dusenberry JA (1991) Advances in oceanography through flow cytometry. In: Demers S, Lewis M (eds) Particle analysis in oceanography. Springer-Verlag, Berlin, p 351-399

Parsons TR, Maita Y, Lalli CM (1984) A manual of chemical and biological methods for seawater analysis. Pergamon Press, Oxford

Peterson BJ, Chester CM, Jochem FJ, Fourqurean JW (2006) Potential role of sponge communities in controlling phytoplankton blooms in Florida Bay. Mar Ecol Prog Ser 328:93-103 
Phlips EJ, Badylak S (1996) Spatial variability in phytoplankton standing crop and composition in a shallow inner-shelf lagoon, Florida Bay, Florida. Bull Mar Sci 58: 203-216

Phlips EJ, Zeman C, Hansen P (1989) Growth, photosynethesis, nitrogen fixation and carbohydrate production by a unicellular cyanobacterium, Synechococcus sp. (Cyanophyta). J Appl Phycol 1:137-145

Phlips EJ, Badylak S, Lynch TC (1999) Blooms of the picoplanktonic cyanobacterium Synechococcus in Florida Bay, a subtropical inner-shelf lagoon. Limnol Oceanogr 44:1166-1175

Pile AJ, Patterson MR, Savarese M, Chernykh VI, Fialkov VA (1997) Trophic effects of sponge feeding within Lake Baikal's littoral zone. 2. Sponge abundance, diet, feeding efficiency, and carbon flux. Limnol Oceanogr 42:178-184

Reiswig HM (1971a) Particle feeding in natural populations of three marine demosponges. Biol Bull 141:568-591

Reiswig HM (1971b) In-situ pumping activities of tropical Demospongiae. Mar Biol 9:38-50

Reiswig HM (1974) Water transport, respiration, and energetic of three tropical marine sponges. J Exp Mar Biol Ecol 14:231-249

Robblee MB, Barber TR, Carlson PR, Durako MJ and others (1991) Mass mortality of the tropical seagrass Thalassia testudinum in Florida Bay (USA). Mar Ecol Prog Ser 71: 297-299

Rohrlack T, Dittmann E, Henning M, Borner T, Kohl JG (1999) Role of microcystins in poisoning and food ingestion inhibition of Daphnia galeata caused by the cyanobacterium Microcystis aeruginosa. Appl Environ Microbiol 65:737-739

Rudnick DT, Chen Z, Childers DL, Boyer JN, Fontaine TD (1999) Phosphorus and nitrogen inputs to Florida Bay: the importance of the everglades watershed. Estuaries 22:398-416

SERC-FIU (2007) Southeast Environmental Research Center - Florida International University (Data were provided by the SERC-FIU Water Quality Monitoring Network which is supported by SFWMD/SERC Cooperative Agreement \#4600000352 as well as EPA Agreement \#X7-96410603-3)

Editorial responsibility: Joseph Pawlik, Wilmington, North Carolina, USA
Shumway SE (1990) A review of the effects of algal blooms on shellfish and aquaculture. J World Aquacult Soc 21: 65-104

Smaal AC, Prins TC (1993) The uptake of organic matter and the release of inorganic nutrients by bivalve suspension feeder beds. In: Dame RF (ed) Bivalve filter feeders in estuarine and coastal ecosystem processes. SpringerVerlag, Berlin, p 271-298

Sokal RR and Rohlf FJ (1995) Biometry. W. H. Freeman and Co., New York, NY

Stevely JM, Sweat DE (1998) Survey of recovery of Florida Keys sponge populations following a widespread sponge mortality. Report no. MR252, Florida Sea Grant Extension Program, Tallahassee, FL

Sunda WG, Graneli E, Gobler CJ (2006) Positive feedback and the development and persistence of ecosystem disruptive algal blooms. J Phycol 42:963-974

> Turon X, Galera J, Uriz MJ (1997) Clearance rates and aquiferous systems in two sponges with contrasting lifehistory strategies. J Exp Zool 278:22-36

Vogel S (1994) Life in moving fluids. Princeton University Press, Princeton, NJ

> Wall CC, Peterson BJ, Gobler CJ (2008) Facilitation of seagrass Zostera marina productivity by suspension-feeding bivalves. Mar Ecol Prog Ser 357:165-174

Ward JE, Levinton JS, Shumway SE, Cucci T (1998) Particle sorting in bivalves: in vivo determination of the pallial organs of selection. Mar Biol 131:283-292

Weisz JB, Lindquist N, Martens CS (2008) Do associated microbial abundances impact marine demosponge pumping rates and tissue densities? Oecologia 155:367-376

> Yahel G, Sharp JH, Marie D, Hase C, Genin A (2003) In situ feeding and element removal in the symbiont-bearing sponge Theonella swinhoei: bulk DOC is the major source for carbon. Limnol Oceanogr 48:141-149

- Yahel G, Marie D, Genin A (2005) InEx - a direct in situ method to measure filtration rates, nutrition, and metabolism of active suspension feeders. Limnol Oceanogr Methods 3:46-58

Zar JH (1998) Biostatistical analysis, 4th ed. Prentice Hall, Englewood Cliffs, NJ

Submitted: September 11, 2011; Accepted: November 30, 2011 Proofs received from author(s): March 28, 2012 